\title{
STRATEGI BERSAING PRODUK BNI TAPLUS BISNIS DENGAN PENDEKATAN BCG MATRIX PADA BANK BNI KC HARMONI
}

\author{
Roberta Ribka Pingkan Gosal \\ Program Studi Magister Manajemen Universitas Tarumanagara \\ pingkangosal@gmail.com \\ Haris Maupa \\ Program Studi Magister Manajemen Universitas Tarumanagara
}

Masuk : 07-12-2020, revisi : 23-12-2020, diterima untuk diterbitkan : 28-12-2020

\begin{abstract}
This research was conducted to determine the competitive strategy of the "BNI Taplus Bisnis" product issued by the Indonesian State Bank (BNI) by employing the Boston Consulting Group (BCG) Matrix. This research was done by interviewing the Head of Main Branch Marketing, Supervisor Marketing, Marketing Staff, Head of Support Branch. Equipped by the questionnaire for the representative of each division. The results of the IFE and EFE matrices showed that the total value for IFE is 2.07, while the total value for EFE is 2.12. The SWOT Matching Stage consists of several possible strategies obtained by using the strengths you have to take advantage of opportunities, take advantage of opportunities to overcome weaknesses, use your strengths to avoid threats, and minimize weaknesses to avoid threats. In the Internal-External (IE) matrix, it is known that BNI Taplus Bisnis is in the position of Cell $\mathrm{V}$, the most suitable strategies for this position are market penetration strategy and product development strategy. While the results of the analysis using the BCG Matrix are obtained from the position of BNI Taplus Bisnis being in the Dog's Position, so that strategies can be carried out by reducing production costs or marketing costs of this BNI Taplus Bisnis product. This is to determine the existence of these products. If it is not supported to be maintained, the strategy to get rid of the existing product can be done.
\end{abstract}

Keywords: BCG Matrix, BNI Taplus Bisnis, EFE, IFE, Strategy, SWOT

Abstrak: Penelitian bertujuan untuk menentukan strategi bersaing produk BNI Taplus Bisnis dengan pendekatan BCG Matrix pada Bank BNI KC Harmoni. Penelitian dilakukan dengan cara melakukan wawancara dengan pemimpin bidang Pemasaran, penyelia Pemasaran, staf Pemasaran, dan pimpinan KCP. Pengumpulan data dilengkapi dengan kuesioner bagi perwakilan masing-masing bagian dalam lingkup BNI KC Harmoni. Hasil analisis matriks IFE dan EFE diperoleh total nilai untuk IFE adalah sebesar 2,07 sedangkan total nilai untuk EFE adalah sebesar 2,12. Dengan menggunakan Matching stage SWOT analysis diperoleh hasil bahwa agar Bank BNI perlu menggunakan kekuatan yang dimiliki dengan memanfaatkan peluang untuk mengatasi kelemahan, menggunakan kekuatan yang dimiliki untuk menghindari ancaman dan meminimalisasikan kelemahan untuk menghindari ancaman. Pada matriks Internal Eksternal (IE) diketahui bahwa BNI Taplus Bisnis berada pada posisi Sel V, strategi yang paling cocok pada posisi ini adalah strategi penetrasi pasar dan strategi pengembangan produk. Sedangkan hasil analisis menggunakan BCG Matrix diperoleh bahwa posisi BNI Taplus Bisnis berada pada Posisi Anjing (Dog). Ini menunjukkan strategi yang dapat dilakukan yakni dengan cara mengurangi biaya produksi, ataupun biaya pemasaran dari Produk BNI Taplus Bisnis ini. Strategi ini penting untuk mempertahankan keberadaan produk tersebut. Namun jika sudah tidak memungkinkan untuk dipertahankan, strategi membuang produk yang ada dapat dilakukan.

Kata Kunci: BCG Matrix, BNI Taplus Bisnis, EFE, IFE, Strategi, SWOT 


\section{PENDAHULUAN}

BNI bukanlah satu-satunya bank yang mengeluarkan tabungan bisnis. Maka dari itu, BNI Taplus Bisnis ini harus memiliki "keunggulan/uniqueness" jika dibandingkan dengan produkproduk sejenis lainnya dari bank kompetitor. Produk-produk subtitusi yang dikeluarkan oleh lembaga keuangan lainnya juga menjadi saingan produk ini. Strategi pemasaran produk ini berpengaruh pada eksistensi produk ini. Apakah pertumbuhan produk BNI Taplus ini masih berpeluang untuk bertahan dan bersaing dengan produk dari pesaingnya atau tidak.

Hakim et al. (2016) mengatakan bahwa BCG Matrix adalah salah satu alat bantu yang cukup valid dalam penggunaan dasar saat pembuatan keputusan yang paling mudah apabila dibandingkan dengan jenis matrik-matrik lainnya. Hanya dengan membaca grafiknya saja, pebinis akan dengan mudah dapat melihat sedang berada pada posisi manakah perusahaan mereka berada.

Dengan banyaknya cabang yang melakukan evaluasi menggunakan analisis menggunakan BCG Matrix ini, harapannya dapat membantu pengembangan produk dan perusahaan ini kedepannya. Evaluasi produk dalam tingkat Kantor Cabang dengan metode ini akan menghasilkan nilai yang lebih kuat pengaruhnya untuk pengembangan produk dan perusahaan secara menyeluruh. Oleh karena itu, untuk memulainya maka penelitian ini dilakukan.

\section{Tujuan Penelitian}

Tujuan penelitian ini adalah untuk menentukan strategi yang akan dilakukan perusahaan kedepannya. Melakukan evaluasi terhadap pelaksanaan strategi bersaing BNI Taplus Bisnis dalam menghadapi persaingan juga menjadi tujuan penelitian ini dilakukan. Selanjutnya, untuk menganalisis strategi dari aspek kekuatan dan kelemahan serta peluang dan tantangan bagi BNI Taplus Bisnis yang berguna dalam menghadapi tantangan persaingan. Dan terakhir untuk menganalisis Posisi Produk BNI Taplus Bisnis pada BCG Matrix

\section{TELAAH KEPUSTAKAAN}

Pearce II dan Robinson (2014) berpendapat bahwa strategi adalah rencana dengan skala yang besar, yang berorientasi pada masa depan. Tujuannya adalah untuk berinteraksi dengan kondisi persaingan dalam mencapai tujuan kedepannya. Sedangkan David (2011) menyatakan bahwa strategi adalah sarana bersama yang hendak dicapai dengan tujuan jangka panjang. Strategi bisnis ini mencakup diverifikasi, akusisi, penetrasi pasar, ekspansi geografis, pengetatan, investasi, likuidasi, pengembangan produk dan usaha patungan atau joint venture. Strategi adalah aksi yang potensial dan membutuhkan keputusan manajemen tertinggi dan sumber daya perusahaan dengan jumlah yang besar.

Setiyanto dan Hidayati (2017) mengatakan bahwa Matrik SWOT adalah alat yang dipakai untuk menyusun faktor-faktor strategis perusahaan adalah matrik SWOT. Matrik ini dapat mengambarkan secara jelas bagaimana peluang dan ancaman eksternal yang dihadapi perusahaan dapat disesuaikan dengan kekuatan dan kelemahan yang dimilikinya. Matrik ini dapat menghasilkan 4 set kemungkinan alternatif strategis yaitu yang pertama adalah Strategi SO (Strength-Opportunities) Strategi ini dibuat berdasarkan jalan pikiran perusahaan, yaitu dengan memanfaatkan seluruh kekuatan untuk merebut dan memanfaatkan peluang yang sebesar-besarnya. Kedua adalah strategi ST (Strenghts-Threats) yaitu strategi dalam menggunakan kekuatan yang dimiliki perusahaan untuk mengatasi ancaman. Kemudian Strategi WO (Weaknesses-Opportunities) diterapkan berdasarkan pemanfaatan peluang yang ada dengan cara meminimalkan kelemahan yang ada. Strategi WT (Weaknesses-Threats).

Kotler dan Keller (2009) mengatakan bahwa metode Matriks Boston Consulting Group (BCG) adalah metode yang digunakan dalam menyusun strategi perencanaan unit bisnis dengan cara mengklasifikasi potensi keuntungan dari suatu perusahaan tersebut. Terdapat empat kuadran Matriks yang dimana masing-masing kuadran menggambarkan posisi suatu unit bisnis menurut pandangan dari segi pertumbuhan pasar beserta dengan pangsa pasarnya. 


\section{METODOLOGI PENELITIAN}

Metode penelitian yang digunakan dalam penelitian ini adalah metode kualitatif deskriptif. Pengumpulan data dilakukan dengan mengumpulkan data primer yaitu diperoleh dari hasil interview terhadap Wakil Pimpinan bidang Pemasaran, Penyelia Pemasaran, Staf Pemasaran, Pimpinan KCP dalam lingkup BNI KC Harmoni beserta dengan kuesioner yang diberikan kepada perwakilan tiap bagian. Kemudian data sekunder diperoleh dari data-data internal/laporan perusahaan, seperti Laporan Bulanan, Laporan Tahunan, Website perusahaan, serta data internal lainnya. Sumber lainnya juga berasal dari penelitian terdahulu, jurnal, artikel, text-book, dan sumber lainnya yang berkaitan dengan topik penelitian.

\section{Metode Analisis}

Metode analisis data adalah proses pencarian dan pengumpulan data dan menyusunannya secara sistematis. Data yang ada diperoleh dari hasil wawancara, dengan lisan maupun tertulis. Lalu membaginya ke dalam kategori yang dibutuhkan. Selanjutnya dibuat kesimpulan agar lebih mudah dimengerti oleh kalangan umum. Kemudian, teori yang ada digunakan oleh peneliti dengan membandingkan kenyataan yang terjadi di lapangan. Setelah data telah diperoleh peneliti, maka selanjutnya akan melakukan pengolahan data dan analisa data tersebut sehingga menghasilkan sebuah pembahasan berbentuk penjelasan terkait Analisis SWOT dan kondisi yang ada pada produk BNI Taplus Bisnis. Selanjutnya dilakukan analisis posisi keberadaan produk dalam persaingan dengan menggunakan Matrik BCG.

\section{HASIL DAN PEMBAHASAN}

\section{Analisis Matriks Internal Factor Evaluation (IFE) \& External Factor Evaluation (EFE) Tabel 1}

Analisis Matriks IFE EFE

\begin{tabular}{|c|c|c|c|c|c|c|c|c|c|c|c|}
\hline \multirow[b]{2}{*}{ Faktor-faktor Strategi Internal } & \multicolumn{5}{|c|}{ Bobot } & \multicolumn{5}{|c|}{ Rating } & \multirow[t]{2}{*}{ Nilai } \\
\hline & Ml & M2 & M3 & M4 & $\begin{array}{l}\text { Rata- } \\
\text { Rata }\end{array}$ & MI & M2 & \begin{tabular}{|c|}
$M$ \\
\end{tabular} & \begin{tabular}{|c|c|}
$M$ & \\
4 & \\
\end{tabular} & \begin{tabular}{|l|} 
Rata \\
Rata
\end{tabular} & \\
\hline \multicolumn{12}{|l|}{ Kekuatan (S) } \\
\hline 1. BNI Taplus Bisnis mempunyai fitur mutasi rekening secara terperinci & 0.03 & 0.03 & 0.03 & 0.05 & 0.03 & 1 & 1 & 1 & 1 & 1 & 0.03 \\
\hline 2. Limit transaksi per harinya lebih tinggi daripada produk lainnya & 0.1 & 0.06 & 0.06 & 0.09 & 0.08 & 2 & 2 & 2 & 2 & 2 & 0.15 \\
\hline 3. Dilengkapi fasilitas pendukung yang memudahkan perusahaan/pelaku bisnis yaitu BNI Direct & 0.13 & 0.11 & 0.11 & 0.09 & 0.11 & 3 & 3 & 3 & 2 & 3 & 0.31 \\
\hline 4. Mempunyai fasilitas sweep account untuk mengatur saldo rekening perusahaan & 0.13 & 0.11 & 0.08 & 0.07 & 0.10 & 3 & 3 & 2 & 2 & 3 & 0.25 \\
\hline 5. Memudahkan perusahaan/pelaku usaha dalam memantau cash flow setiap bulannya. & 0.07 & 0.09 & 0.08 & 0.09 & 0.08 & 2 & 2 & 2 & 2 & 2 & 0.17 \\
\hline 6. Dilengkapi fitur mesin EDC bagi pelaku usaha (wirausahawan) & 0.1 & 0.09 & 0.11 & 0.05 & 0.09 & 2 & 2 & 3 & 1 & 2 & 0.17 \\
\hline 7. Dilengkapi dengan fitur mobile banking & 0.07 & 0.09 & 0.08 & 0.09 & 0.08 & 2 & 2 & 2 & 2 & 2 & 0.17 \\
\hline & & & & & & & & & & & \\
\hline \multicolumn{12}{|l|}{ Kelemahan (W) } \\
\hline 1. Saldo minimum per bulannya cukup tinggi. & 0.07 & 0.06 & 0.06 & 0.05 & 0.06 & 2 & 2 & $2 \mid$ & 1 & 2 & 0.10 \\
\hline 2. Biaya administrasi relatif tinggi & 0.03 & 0.06 & 0.06 & 0.07 & 0.05 & 1 & 2 & \begin{tabular}{|l|l}
2 & $r$ \\
\end{tabular} & 2 & 2 & 0.09 \\
\hline 3. Tidak adanya potongan biava transfer & 0.03 & 0.06 & 0.08 & 0.09 & 0.07 & 1 & 3 & 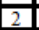 & 2 & 2 & 0.13 \\
\hline 4. Bunga belum mampu bersaing & 0.1 & 0.09 & 0.08 & 0.07 & 0.09 & 2 & 2 & 2 & 2 & 2 & 0.17 \\
\hline 5. Limit transaksi perharinya kurang difokuskan pada kebutuhan transaksional bisnis & 0.07 & 0.09 & 0.08 & 0.09 & 0.08 & 2 & 2 & 2 & 2 & 2 & 0.17 \\
\hline 6. Hanya diperuntukkan bagi pelaku bisnis menengah keatas & 0.07 & 0.06 & 0.08 & 0.09 & 0.08 & 2 & 2 & 2 & 2 & 2 & 0.15 \\
\hline Total & 1 & 1 & 1 & 1 & 1 & & & 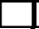 & & & 2.07 \\
\hline Faktor-faktor Strategi Eksternal & & & Bobot & & & & & atin & & & Nilai \\
\hline & Ml & M2 & M3 & M4 & $\begin{array}{l}\text { Rata } \\
\text { Rata }\end{array}$ & Ml & M2 & M3 & M4 & $\begin{array}{l}\text { Rata } \\
\text { Rata }\end{array}$ & \\
\hline \multicolumn{12}{|l|}{ Peluang (O) } \\
\hline 1. Banyaknya pelaku-pelaku usaha menengah ke bawah & 0.08 & 0.09 & 0.09 & 0.08 & 0.08 & 2 & 2 & 2 & 2 & 2 & 0.16 \\
\hline 2. Banyaknya perusahaan yang masih kesulitan mengatur cash flow dalam rekening yang berbeda-beda & 0.05 & 0.06 & 0.09 & 0.10 & 0.07 & 1 & 2 & 2 & 2 & 2 & 0.13 \\
\hline 3. Era digitalisasi yang memungkinkan segala sesuatunya dilakukan secara online & 0.11 & 0.11 & 0.11 & 0.10 & 0.11 & 3 & 3 & 3 & 2 & 3 & 0.30 \\
\hline 4. Adanya program pemerintah dalam mengembangkan UKM (Usaha Kecil Menengah) & 0.08 & 0.06 & 0.09 & 0.08 & 0.07 & 2 & 2 & 2 & 2 & 2 & 0.15 \\
\hline 5. Banyaknya perusahaan start up yang bermunculan & 0.08 & 0.09 & 0.06 & 0.05 & 0.07 & 2 & 2 & 2 & 1 & 2 & 0.12 \\
\hline 6. Kepercayaan masyarakat terhadap perbankan BUMN & 0.11 & 0.09 & 0.06 & 0.08 & 0.08 & 3 & 2 & 2 & 2 & 2 & 0.18 \\
\hline & & & & & & & & & & & \\
\hline \multicolumn{12}{|l|}{ Ancaman $(\mathrm{T})$} \\
\hline 1. Banyaknya kompetitor yang menawarkan fitur yang lebih lengkap & 0.11 & 0.11 & 0.11 & 0.10 & 0.11 & 3 & 3 & 3 & 2 & 3 & 0.30 \\
\hline 2. Adanya kompetitor dengan limit transaksi yang tidak terbatas per harinya & 0.05 & 0.09 & 0.09 & 0.10 & 0.08 & 1 & 2 & 2 & 2 & 2 & 0.14 \\
\hline 3. Perubahan perilaku konsumen yang mempengaruhi keberlangsungan perusahaan/pelaku bisnis & 0.08 & 0.09 & 0.06 & 0.05 & 0.07 & 2 & 2 & 2 & 1 & 2 & 0.12 \\
\hline 4. Adanya kompetitor yang menggratiskan biaya transfer & 0.05 & 0.06 & 0.09 & 0.10 & 0.07 & 1 & 2 & 2 & 2 & 2 & 0.13 \\
\hline 5. Tawaran bunga yang lebih tinggi dari kompetitor & 0.11 & 0.09 & 0.09 & 0.05 & 0.08 & 3 & 2 & 2 & 1 & 2 & 0.16 \\
\hline 6. Munculnya inovasi lainnya yang lebih dulu dilakukan oleh kompetitor & 0.11 & 0.09 & 0.09 & 0.10 & 0.09 & 3 & 2 & 2 & 2 & 2 & 0.21 \\
\hline Total & 1 & 1 & 1 & 1 & 1 & & & & & & 2.12 \\
\hline
\end{tabular}


Dari perhitungan pembobotan rata-rata tertimbang yang dilakukan terhadap faktor internal perusahaan, didapatkan bahwa matriks IFE menghasilkan skor tertimbang sebesar 2,07 dan matriks EFE menghasilkan skor tertimbang 2,12. Melihat dari rata-rata tertimbang posisi internal dan eksternalnya, produk ini terbilang lemah dalam perusahaan. Artinya baik untuk memanfaatkan kekuatan dan peluang, serta meminimalisir kekurangan dan mengantisipisai ancaman juga tidak terlalu menjadikan produk ini sebagai produk andalan dalam perusahaan. Matriks SWOT sebagai Evaluasi dan Saran dalam Pengembangan Produk

Strategi yang ada bersumber dari hasil interview dan kuesioner yang diberikan oleh peneliti. Strategi yang dihasilkan dapat digunakan sebagai bahan evaluasi terhadap pelaksanaan strategi bersaing BNI Taplus Bisnis dalam menghadapi persaingan.

\section{Tabel 2}

Analisis Matriks SWOT

\begin{tabular}{|c|c|}
\hline Kekuatan & Kelemahan \\
\hline $\begin{array}{l}\text { 1. BNI Taplus Bisnis mempunyai fitur mutasi rekening secara } \\
\text { terperinci }\end{array}$ & 1. Saldo minimum per bulannya cukup tinggi \\
\hline 2. Limit transaksi per harinya lebih tinggi daripada produk lainnya & 2. Biaya administrasi relatif tinggi \\
\hline $\begin{array}{l}\text { 3. Dilengkapi fasilitas pendukung yang memudahkan } \\
\text { perusahaan/pelaku bisnis yaitu BNI Direct }\end{array}$ & 3. Tidak adanya potongan biaya transfer \\
\hline $\begin{array}{l}\text { 4. Mempunyai fasilitas sweep account untuk mengatur saldo } \\
\text { rekening perusahaan }\end{array}$ & 4. Bunga belum mampu bersaing \\
\hline $\begin{array}{l}\text { 5. Memudahkan perusahaan/pelaku usaha dalam memantau cash } \\
\text { flow setiap bulannya }\end{array}$ & $\begin{array}{l}\text { 5. Limit transaksi perharinya kurang difokuskan pada kebutuhan } \\
\text { transaksional bisnis }\end{array}$ \\
\hline 6. Dilengkapi fitur mesin EDC bagi pelaku usaha (wirausahawan) & 6. Hanya diperuntukkan bagi pelaku bisnis menengah keatas \\
\hline \multicolumn{2}{|l|}{ 7. Dilengkapi dengan fitur mobile banking } \\
\hline Peluang & Ancaman \\
\hline 1. Banyaknya pelaku-pelaku usaha menengah ke bawah & $\begin{array}{l}\text { 1. Banyaknya kompetitor yang menawarkan fitur yang lebih } \\
\text { lengkap }\end{array}$ \\
\hline $\begin{array}{l}\text { 2. Banyaknya perusahaan yang masih kesulitan mengatur cash flow } \\
\text { dalam rekening yang berbeda-beda }\end{array}$ & $\begin{array}{l}\text { 2. Adanya kompetitor dengan limit transaksi yang tidak terbatas per } \\
\text { harinya }\end{array}$ \\
\hline $\begin{array}{l}\text { 3. Era digitalisasi yang memungkinkan segala sesuatunya } \\
\text { dilakukan secara online }\end{array}$ & $\begin{array}{l}\text { 3. Perubahan perilaku konsumen yang mempengaruhi } \\
\text { keberlangsungan perusahaan/pelaku bisnis }\end{array}$ \\
\hline $\begin{array}{l}\text { 4. Adanya program pemerintah dalam mengembangkan UKM } \\
\text { (Usaha Kecil Menengah) }\end{array}$ & 4. Adanya competitor yang menggratiskan biaya transfer \\
\hline 5. Banyaknya perusahaan start up yang bermunculan & 5. Tawaran bunga yang lebih tinggi dari competitor \\
\hline 6. Kepercayaan masyarakat terhadap perbankan BUMN & $\begin{array}{l}\text { 6. Munculnya inovasi lainnya yang lebih dulu dilakukan oleh } \\
\text { kompetitor }\end{array}$ \\
\hline
\end{tabular}

\section{Matriks IE untuk Penentuan Strategi yang akan dilakukan kedepannya}

Matrik IE digunakan untuk merumuskan strategi IFE dan EFE. Produk BNI Taplus Bisnis memiliki total nilai 2,07 pada faktor internal dan total nilai 2,12 pada factor eksternal. Produk BNI Taplus bisnis berada pada Sel V, yang nantinya akan menggunakan strategi penetrasi pasar dan pengembangan produk.

Matriks BCG dan Strategi yang seharusnya dilakukan Menanggapi Hasil yang diperoleh Gambar 1

BCG Matrix BNI Taplus Bisnis

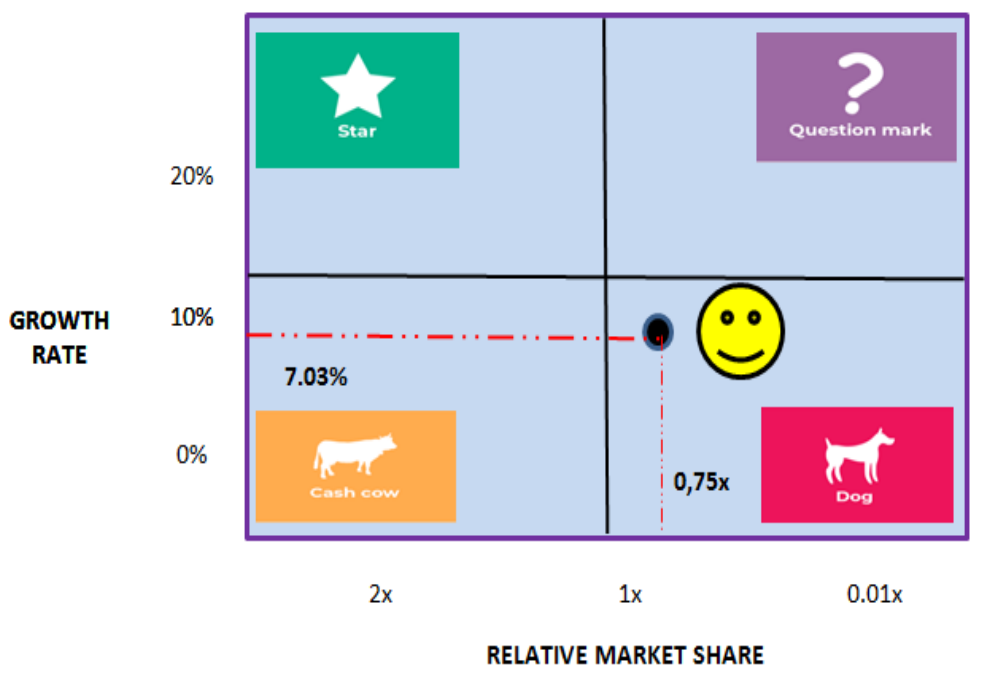


Berdasarkan Gambar 1, Growth Rate yang dihasilkan sebesar 7,03\%, sedangkan Relative Market Share yang dihasilkan sebesar 0,75 kali. Hasil tersebut menempatkan posisi BNI Taplus Bisnis pada Bisnis dengan kategori Dog (Anjing). Hal ini berarti BNI Taplus Bisnis adalah produk yang menghasilkan cukup uang untuk mencapai titik impas dengan biaya yang sudah dikeluarkan perusahaan sebelumnya untuk pengembangan produk ini kedepannya. Perusahaan terbilang jarang berinvestasi pada kategori ini karena dianggap hamper tidak layak. Sebaliknya, produk ini akan menguras kas karena biaya yang digunakan cenderung lebih banyak daripada penghasilan yang diperoleh.

\section{KESIMPULAN DAN SARAN}

Berdasarkan hasil strategi yang dapat dilakukan Bank BNI KC Harmoni kedepannya dalam menghadapai persaingan yaitu dengan banyak mengembangkan fasilitas online seperti mobile banking dan BNI Direct. Hal ini dilakukan karena dengan cara ini segala macam persoalan dapat diatasi seperti tidak adanya biaya transfer dan biaya administrasi. Apalagi cara ini sejalan juga dengan perkembangan jaman. Kemudian lebih memfokuskan target pemasaran kepada pelaku bisnis menengah ke atas, dan perusahaan menengah ke atas. Hal ini karena dana segar yang masuk lebih banyak. Strategi yang dapat dilakukan untuk mempertahankan produk dengan penetrasi pasar dan pengembangan produk. Produk ini berada pada posisi yang kurang baik untuk dikembangkan. Pilihannya adalah untuk mempertahankan eksistensi dengan cara mengurangi biaya produksi dan pemasaran atau menghilangkannya. Strategi yang dilakukan dalam menanggapi hasil dari posisi BCG Matrix yang ada adalah dengan cara mengurangi biaya produksi, ataupun biaya pemasaran dari Produk BNI Taplus Bisnis ini. Hal tersebut guna untuk mempertahankan keberadaan produk tersebut. Apabila sudah tidak memungkinkan untuk dipertahankan, strategi membuang produk yang ada dapat dilakukan. Membuang produk dapat dilakukan dengan dua opsi, meniadakan atau mengganti dengan produk dengan inovasi baru. Adapun kelemahan dari metode BCG Matrix ini adalah sulitnya mengetahui pangsa pasar yang ada, sehingga saran untuk penelitian ini kedepannya adalah untuk mencari lebih dalam lagi data yang dibutuhkan sesuai dengan pangsa pasar yang seharusnya.

\section{DAFTAR PUSTAKA}

David, F. R. (2011). Strategic management: Concepts and cases (13th ed.). Prentice Hall.

Hakim, S. Al, Habibi, M. M., \& Sudirman, S. (2016). Implementasi kebijakan remunerasi dalam meningkatkan kinerja pegawai negeri sipil (PNS) di Fakultas Ilmu Sosial Universitas Negeri Malang. Jurnal Ilmiah Administrasi Publik, 2(3), 65-73. https://doi.org/10.21776/ub.jiap.2016.002.03.9

Kotler, P., \& Keller, K. L. (2009). Manajemen pemasaran (Millenium, Vol. 2). Erlangga.

Pearce II, J. A., \& Robinson, Jr., R. B. (2014). Manajemen strategis: Formulasi, implementasi, dan pengendalian (N. P. Sari (ed.); 1st ed.). Salemba Empat.

Setiyanto, A. I., \& Hidayati, S. N. (2017). Pengaruh kepuasan kerja dan komitmen organisasi terhadap turnover intention. Jurnal Akuntansi, Ekonomi Dan Manajemen Bisnis, 5(1), 105. https://doi.org/10.30871/jaemb.v5i1.439 